\title{
Language Development Through Drama in Preschoolers
}

\author{
Sindorela Doli Kryeziu \\ Prof. Ass. Dr., University of Gjakova, Faculty of Education, \\ Professor of Albanian language, Kosovo
}

\begin{abstract}
The child develops as a whole, in all developmental areas. The overestimation or underestimation of any field is a mistake because the child does not develop once in the physical aspect, then emotional, intellectual, and so on. Therefore, the division between the fields is also largely formal. Just as the child's development is thorough, specific areas of development must also be seen as part of a whole, the effectiveness of which depends largely on the level of integration between them. One of the most important infrastructures of today's society of information is education, the main purpose of which is the preparation of creative and innovative people. Education has developed an integrated approach to early childhood education, which naturally combines the process of education, health care, education, child play, artistic education and professional care to their development. In this context, important steps were taken regarding preschool education such as in designing methods for pre-school education, drafting general standards of pre-school education and pre-school curricula / preparatory classes. In order to have a genuine linguistic development an important step is artistic education, which includes a wide range of activities. In this field are summarized all the activities that enable the child to communicate through visual presentation, musical sound, dramatic expression, audiovisual means, etc. Artistic education introduces children with elements of art, entertains and offers them opportunities to develop artistic "gift". Fields of art, which traditionally take place in the activities of preparatory classes, are music, applied art, graphics and drawing. An important place in artistic education has won the theater activity and mass media. Therefore, we will deal in our paper with their language development through drama.
\end{abstract}

Keywords: developing fields development areas, education, pre-school education, encouragement and promotion.

\section{Introduction}

Many factors influence the healthy development of children. But the purpose of our work is the highest focus of the development of various artistic activities, namely through artistic education, ie through art.

Audiovisual communication is powerful, the messages that children receive are many and varied. Artistic education introduced children to elements of art, entertains them and enables them to develop the artistic "gift". Traditionally, fields of art that take place in the kindergarten activities, are music, applied arts, graphics and drawing. An important place in artistic education has won theater and mass media.

Drawing for the child is an important tool for describing and understanding reality. Through it, the child learns to paint a thought, a word, an event.

Musical activity, vocal activity and dance:

The content of musical activity summarizes: the recognition and distinction of environmental sounds; the use of sound sounds; the use of traditional and electronic tools and instruments;

Whereas vocal activity: different songs for children; singing games and the music of fairy tales, stories, simple poems;

Listening to music:

Identifying the sounds of reality that surrounds the child; listening to different melodies; 
The acquisition of the listening art; the prolongation of a sound; intensity; pitch of a sound; song fragments and perception and reproduction of rhythm and melody.

Dramatic activity:

It aims to develop the predispositions of the theatrical game in children, to develop imagination, the desire to express and act in the framework of a theatrical play.

\section{Mass media shows:}

It is the duty of the educator to choose and use in the function of the kindergarten activities radio-television programs, technological games, cartoons and children's films, which can be used with the effectiveness to facilitate and encourage the absorption of active and creative behavior of children.

Applied art:

The child should:

To perceive affectionate relationships with available materials;

Build something by her/his own desire and imagination;

Try different processing alternatives; to use drawing techniques, model, collage; to use the made products; to be expressed in a work that fosters the imagination and ascertains the acheived results.

\section{The drama corner in the preschool education}

Drama in the pre-school children's education aims to change the point of views in the pupil's formation process with a clear vision for his future and his country.

Dramatists pay special attention to cultivating a positive attitude toward children, encouraging students to engage in a rational manner in meeting school requirements, developing skills in everyday life, always taking into account the peculiarities of physical and psychic development of this age.

Dramas in text books in primary education enrich pupils' spiritual values, consolidate knowledge, orientation of trends and skills in building their future. They positively influence the encouragement of pupils to take the initiative of independent action in the family circle and beyond. ${ }^{1}$

In order to achieve effective teaching and learning in the field of dramaturgy, teachers and pupils should use resources and different means of information. So far the main source of information was the textbook of of Albanian literature subject.

In addition to the various textbooks, it is suggested to use other information materials: manuals, brochures, newspapers, cultural and literary journals, photographs, schemes, diagrams, models, pictures, photos, movies, video cassettes, computer programs, internet, cd-s, etc.

It is the competency of the educator that, depending on the conditions in which it works, the school chooses the source of information and teaching aids, paying attention to the balance of oral, visual, auditory and audiovisual data, with particular emphasis on what is essential to be taught.

Learning dramas is a process that never ends, and Therefore, requires great dedication, because it has special importance. Through the drama, basic messages and notions are created and transmitted to the understanding of the self and the social world, as well as the powerful influence it has on the overall development of the individual, both in the emotional, intellectual, social and physical fields. ${ }^{2}$

Dramas affect pupils in the formation of cultured behavior in their own right attitude towards others, tolerance, understanding and mutual assistance.

\footnotetext{
${ }^{1}$ Zejnullah Rrahmani, Teori e letërsisë, sh.b. Faik Konica, Prishtinë, 2008, fq.356

2 Po aty, fq.357.
} 
The emergence of dramas in theaters represents a very favorable and influential resource in the development and in the overall formation of each pupil's personality.

I think that drama as a literary genre in Albanian literature begins to be discussed later compared to the other two literary genres. This is because the development of drama, first of all, requires national freedom. Due to the fact that Albanians lacked freedom, and consequently teaching as well as any other cultural manifestation in their mother tongue, starting from the end of the 15th century until 1912; then it is obvious the reason why the number of dramas in our textbooks is still small.

By watching dramas through theater scenes, pupils acquire new knowledge, they socialize, humanize and prepare much more during their lives.

They need drama because through them the pupils are equipped with a certain ideal that they try to imitate during life. This is the aesthetic ideal through which pupils form social consciousness. Dramas thrill and delight children, make them skillful and train them for their future Dramas teach children to love their parents, their homeland and their lives.

Goethe said, "The writers, the playwrights, are the eyes, ears, and the voice of the time."

Drama should not only be applied as a simple form of reading and commenting by heart. It should be displayed on the stage, the scene in the school premises should be improvised and pupils should play that drama. A greater value that reveals student talent would be to send pupils to the city's professional theater. This is the best method for presenting a children's play. ${ }^{1}$

In this context, the question arises:

- What drama should be offered more in textbooks for pupils?

- What types of dramas are needed the most?

In dramaturgy texts, the pupils must find themselves, the present society with all the advances, values, but also the scarcity and flaws they face in this new century.

In order that children understand what the drama is, the teacher must make a serious preparation. For example, to get a well-known Albanian playwright, satirical and humorist poet Spiro Çomora. A thorough analysis must be made: the educator addresses the pupils:

- Have you ever seen a theater show?

- Would you like to play any role in a show?

- Which theater actors do you know?

Thereafter, discuss the content of the show (the text), the play of actors, their outfits, stage appearance, music etc. This work is done in groups.

This literary genre should be more present in text books, because the live of people on this planet is indeed an interesting drama in which people breathe and live on this earth.

Meanwhile, the life of Albanians is full of great, tragic - comedy drama. ${ }^{2}$

From the old classic tragedy and comedy, in the middle ages, a new kind of dramatic poetry was born which was neither tragedy nor comedy. This design was called drama. With the word drama we understand the compilation of dramatic poetry that contains joyful and serious acts of everyday life.

\footnotetext{
1 Sefedin Fetiu, Krijues dhe Krijime, Rilindja, Prishtinë, 1979, fq. 68.

2 Zejnullah Rrahmani, Teori e letërsisë, sh.b. Faik Konica, Prishtinë, 2008, fq.345
} 


\section{Drama Center}

The drama center / family center is compulsory for preschool children, and is also very important for children of six and seven years of age. In this center, children aged six and seven will try to dramatize the various topics that are foreseen in the curriculum.

The educational team plans, fills and changes the properties ${ }^{1}$ that children use in this country. In one week the properties can be set that will include bathing activities, next week the properties for hair, then the properties for the guard of pets, in other weeks additional properties, according to the wishes of the children. As part of this, the center may also provide cooking facilities. Various cooking projects are particularly interesting and fun for children and enable them to learn scientific concepts, try different foods, eat the food they have prepared themselves, understand mathematical concepts, and so on.

In the drama center / family center or the corner of the drama / family corner there must be clothing and properties that children will try to play different roles, imitate what they see in everyday life, which will help them understand the world around them.

If there is not enough room in the classroom, the drama / family center can only be presented as a box of suitcases and suits. Properties, as well as any costume items (such as hat, gloves, etc.) can help to develop communication as well as dramatize different curriculum topics.

\section{How does our interest in creativity increase?}

"Art is created to be experienced rather than understood. Therefore, whenever explanations are required, stupidities are said"

\section{Dreiser $^{2}$}

Our interest for creativity grows only when we ask the its creator and he does not give information or not satisfactory enough. Since the piece of work that we have in front of us and experience it in the way and on the basis of the knowledge and the cultural value we have, then there can not be the same feeling between us and the creator.

The most popular and intense activity of the child is the game! The child should be encouraged to express and explain what is created. We can say every child that plays behaves like a creator when he creates his own world or, more precisely, when he sets things of his own world in a new order that he likes. ${ }^{3}$

The game is generally considered as the "par excellence" educational context during pre-school years. The importance of learning through the game for the first time was mentioned by the first German educator Friedrich Fröebel (1782 - 1852).

At a later time, Piaget offers psychological reasons for this doctrine, arguing that the active exploration of children with a wide variety of objects is an essential precursor of later verbal and cognitive comprehension. Denying children's opportunities for the game hinders their opportunities for development and education.

The play indisputably supports learning goals by providing opportunities for developing skills and reading, strengthening writing skills, and self-regulating skills. When the game is applied to academic settings, children may prefer the learning process, which helps them become self-motivated and self-managers learners. Generally, the game represents an essential component of the learning process and understanding of the role of the game during this process is necessary by parents and educators. ${ }^{4}$

In today's literature, the imaginative play is mentioned by most scholars about its importance in the learning process, especially in pre-school children.

\footnotetext{
${ }^{1}$ Fjalori elektronik shpjegues: REKUIZITË f. sh. teatër. Tërësia e sendeve që janë të nevojshme për të dhënë një shfaqje ose për të bërë një film (me përjashtim të skenës dhe të veshjeve të aktorëve); vendi ku mbahen e ruhen këto sende.

2 Lefteri Selmani, Konceptimi dhe organizimi i veprimtarisë mësimore educative në arsimin parashkollor, GEER, Tiranë 2006, fq. 123

${ }^{3}$ Haki Xhakli, Artet figurative me metodologji, Universiteti i Prishtinës, Prishtinë, 2014/2015, fq. 44

4 Theodhor Karaj (2005), Psikologjia e zhvillimit të fëmijës, Progres, Tiranë, 2005, fq. 57
} 
The imaginative play involves various forms of "do and believe" activities, including out of context behavior (e.g. when children pretend as if they are eating food), substitute objects (e.g., the use of a toy pacifier to feed the doll). The imaginative play consisted of $17 \%$ of the play during the preschool years and $33 \%$ during the play in the kindergarten.

Psychologist Lev Vygotsky has suggested that the imaginative play is the most spontaneous activity during childhood during which the child functions at a higher intellectual level and higher level of competence compared to all other activities. During the imaginative game these skills are developed: working memory (since when the child claims to be someone else he must remember the role and stay within this character), flexible thinking (they have to adapt to the decisions that other children bring along during the game) and creativity. Different scholars have identified some of the academic benefits of the imaginative game. A study has proved that the quality of the imaginative play has predicted the early writing skills theoretically the fantasy game is a form of symbolic media like writing, and the children who manage to carry their thoughts and feelings into fantasy they are more likely to better in carrying these thoughts in writing in the future. Similarly, children who understand different stories from the perspective of the fantasy play will be able to better understand the contents of stories read to them. ${ }^{1}$

Recognizing the crucial importance of the play in child development experts have designed curricula which use games to promote the development of children's cognitive development but also to teach them reading and writing skills.

For example, Bodrova and Leong's $(2001,2003)$ have designed the program "Tools of the Mind" a program dedicated to preschool classes and children attending kindergarten. This program pays particular importance to the application of sociodramatic games in the promotion of writing and reading skills based on the principles of Vygotsky's theory and the work of his student Elkon. These classes include spaces where dramatic games are developed and where children spend a good part of time engaging in dramatic activities.

Educators support the children's game by helping them create imaginary situations by providing scenic material and enabling the gaming process to be prolonged. Children with the support of the educator draw up script scenarios where they include the theme, roles, and rules on which the game is based.

For example, the educator helps children to enrich the vocabulary with new words when she/he introduces the material of the scene e.g.: during the play of the game "doctor's office" the teacher introduces the stethoscope or needle to the children. The first writing skills then develop when the children try to describe the prescriptions. Numerous skills are also developed during this game. Pre-mathematical skills are also developed during socio-dramatic games (e.g. presentation of height and weight chart at the doctor's office). ${ }^{2}$

\section{Dramatic play}

The dramatic play is a self-directed spontaneous activity, through which children test, clarify and enhance the meaning of themselves and their world. Although the details of the children's play vary in different parts of the world and cultures, the theme of their game is the same. In their game, children recreate places and scenes that are familiar to them, imitate family members' behaviors, and take different roles of different people in their communities. They reproduce the world as they understand it, or as it confuses and scares them.

Ever since childhood, children imitate the sounds they hear and the activities they watch. Being satisfied with their pretenses, children respond to new situations through movement and sound. In a word, they play. This game, when encouraged becomes a drama: an artistic form, a social activity and a form of learning. ${ }^{3}$

The dramatic play happens when the child claims to be someone else or plays a role. An example of this game may be the moment the child wears a cape and claims to be a superhero.

The dramatic game helps develop language and vocabulary, enhances memory skills, develops flexible and discovery thinking, etc.

\footnotetext{
1 Erlehta Mato, (1995), Disa veçori psikologjike dhe sociale të parashkollorit, Tiranë, 1995, fq. 36

2 Po aty, fq. 37

3 Pamela A. Couglin, Krijimi i klasave me fëmijët në epiqendër: fëmijët 3-5 vjeçarë, sh.b. CRI, Tiranë, 1997, fq. 157
} 
Socio-dramatic plays - are considered when two or more children participate in the game.

An instance may be when children play imaginative school role play game where one becomes a teacher and the other the pupil.

According to the Piaget, socio-dramatic plays develop abstract thinking, refine children's understanding of the world, and they also learn how to solve problems in a safe environment. ${ }^{1}$

\section{The impact on developmental areas}

In dramatic play, children spontaneously pretend to be someone else or imitate their behavior (by extinguishing extinguish fire as a firefighter), using something that symbolizes something else (sitting on a block driving the road) and using the pretense to interpret known events (going to the grocery store). For pre-school children, this is the ideal field of emotional and meaningful learning. The dramatic play affects all areas of child development. If the educator builds the activities properly, both the mind and the body become the subject of appropriate developmental experiences.

In the drama and creative play, the preschool child can experience activities that:

Help develop the five senses.

Encourage expressive language skills.

Help them find patterns and understand relationships.

Create connections.

Facilitate creative thinking and problem solving.

Increase self-esteem.

Develop expression of emotions and feelings.

Develop small and large motor skills.

Sing to joy and childhood freedom.

Through dramatic play, children learn to concentrate, to exercise imagination, testing new idea, practice behaviors of adults and develop a sense of control over their own world. Likewise, children gain a high awareness of the beauty, rhythm, and structure of their environment as well as of their body by learning more to convey their thoughts, feelings, and emotions.

\section{Communicating with children through acting}

Communication is the process by which information between two or more people is exchanged and understood in order to be motivated or influenced in their behavior or attitudes.

Communication (lat. Cum $=$ to, munire $=$ join, build) is the progress that allows living things to exchange information through several ways and levels. Communication requires all parties to understand a shared language that can be exchanged. Communication represents the process of transferring information from the source through the mediator to the receiver, as well as passing the receiver's response through the mediator to the source. Nowadays the word communication is often used as a synonym for the term "announcement" (e.g. communicated - announced, communication - notification).

Communication can be more understandable through drawing. Why do people have such need to communicate?

During communication there is the exchange of the recommendations of two or more people (student-teacher-parentcommunity), we create relationships with other people, and through these relationships we gain orientation on ourselves and on our behavior, but also experience emotional satisfaction. ${ }^{2}$

\section{Artistic Communication}

Artistic communication means transmitting the artistic message from the creator to the recipient, through the work of art.

Each work communicates with the recipient, broadcasting an artistic content with a certain language. Artistic communication is a four-way process: Creation-transmission-reception-public reaction.

\footnotetext{
1 Ermioni Hoxha Ceka, vep.cit., fq. 254

2 Haki Xhakli, Artet figurative me metodologji, Prishtinë, 2014, fq.18
} 
The manner of artistic communication implies transmitting and receiving certain artistic structures that are both a symbol to be intelligible, it needs to respond to a meaning less or more convenient.

For the symbol to be understandable, it is necessary to respond to a more or less appropriate meaning. Between the provider and the recipient there is a certain distance in the understanding of the symbol; the great affinity between them leads to non artistic expression and to the destruction of artistic taste. While the excessive distance, it causes a communication crisis. Artistic communication is only possible when artistic production is not something important, but something that has a certain form and structure created based on the gathering of artistic and social experience that is common property both for the creators and for the recipient. ${ }^{1}$

\section{Examples of organizing an art corner}

The art center stimulates children to develop and explore their own creativity, to have fun with new materials and experience new sensory experience. In addition to the consumable materials that can be found in this place, many natural materials as well as other materials that can easily be found in the immediate vicinity can be added.

The art center may also contain additional guidelines for the use of various tools and materials for drawings, paintings and collages, and other works through which pupils can express their creativity and imagination.

\section{Conclusion}

While science studies reality as an objective phenomenon, individually in each area, art reflects the same phenomena aesthetically through inner feelings. Thus, the rainbow is studied by physics as an optical phenomenon; the science of physiology deals with metabolic processes, for example flowers; dawn and dusk are studied as a result of the earth revolving around its axis, and so on. Nevertheless, all these processes, phenomena, and objects can be seen from a different point of view, from their aesthetic qualities and features. The rainbow is portrayed in numerous paintings as a specific color harmony; flowers have been the specific object of art as a harmonious combination of symmetrical shapes and different colors; as well as the dawn and dusk with their marvelous images, which expressly and aesthetically show that great beauty, they have been and are still inspiration to almost every artist.

Even the means of expression may be based, both in reason and feeling. For example, we can use words to say the truth, a fact, legitimacy, but the word can also be used as a means of expressing feelings, emotions, as a poetic expression.

Also, the size, shape and geometric figures, e.g. drawings of geographical maps; technical drawings, anatomical drawings, etc., express facts, information about the object, territory, position etc, but on the other hand they can serve as forms, figures, lines and expressions of the respective feelings, ie aesthetic expressions. In this case they are means of figurative, artistic expression. Their relation make the artist express their inner feelings, and the viewer experiences those feelings.

Therefore, art is also the highest form of aesthetic acquisition of reality and imagination, since on the one hand it reflects the many aesthetic phenomena, and on the other hand, it is a creation under the laws of beauty and a creation of new aesthetic values.

\section{References}

[1] Erlehta Mato, (1995), Disa veçori psikologjike dhe sociale të parashkollorit, Tiranë, 1995, fq. 36, 37

[2] Ermioni Hoxha Ceka, vep.cit., fq. 254

[3] Fjalori elektronik shpjegues: REKUIZITË f. sh. teatër. Tërësia e sendeve që janë të nevojshme për të dhënë një shfaqje ose për të bërë një film (me përjashtim të skenës dhe të veshjeve të aktorëve); vendi ku mbahen e ruhen këto sende.

[4] Haki Xhakli, Artet figurative me metodologji, Prishtinë, 2014, fq.18

[5] Haki Xhakli, Artet figurative me metodologji, Universiteti i Prishtinës, Prishtinë, 2014/2015, fq. 44

[6] Lefteri Selmani, Konceptimi dhe organizimi i veprimtarisë mësimore educative në arsimin parashkollor, GEER, Tiranë 2006, fq. 123

[7] Pamela A. Couglin, Krijimi i klasave me fëmijët në epiqendër: fëmijët 3-5 vjeçarë, sh.b. CRI, Tiranë, 1997, fq. 157

1 Tefik Çaushin, Fjalori i Estetikës, OMBRA-GVG, Tiranë, 2013. 
[8] Sefedin Fetiu, Krijues dhe Krijime, Rilindja, Prishtinë, 1979, fq. 68.

[9] Tefik Çaushin, Fjalori i Estetikës, OMBRA-GVG, Tiranë, 2013.

[10] Theodhor Karaj (2005), Psikologjia e zhvillimit të fëmijës, Progres, Tiranë, 2005, fq. 57

[11] Zejnullah Rrahmani, Teori e letërsisë, sh.b. Faik Konica, Prishtinë, 2008, fq.345

[12] Zejnullah Rrahmani, Teori e letërsisë, sh.b. Faik Konica, Prishtinë, 2008, fq.356, 357 